\title{
Factors Affecting Housing Development in Makama Jahun Area of Bauchi Metropolis, Nigeria
}

\author{
Aliyu Ahmad Aliyu, Rozilah Kasim, and David Martin
}

\begin{abstract}
This paper was designed to investigate and examine the problems encountered by private residential property developers in developing their residential accommodation in Makama Jahun neighbourhood of Bauchi Metropolis Two hundred respondents were selected through stratified random sampling. Data were presented using simple percentage distribution tables and complete theoretical analyses were used to analyze data that are not numerical in nature. The analysis revealed that high cost of building materials, non-use of local building materials, low income of the majority of the respondents and poor source finance amongst others were discovered to be the major constraints to residential property development in the study area. Others are problem of land acquisition and statutory regulation which were also among the obstacles faced by the respondents. In other to make a meaningful and adequate coverage the study is limited to Makama Jahun area of Bauchi metropolis. This paper represents the first work that analyse the problems of private residential property development in Makama Jahun neighbourhood of Bauchi metropolis, Nigeria. To arrest this situation, the use of local building materials should be encouraged by the respondents. Financial institutions should scale down on their stringent lending requirements for a building loan. The chains of schedule in formal land acquisition should be reduced by the government and thereby quicken acquisition process. If these are followed, it will help to combat residential development problems identified in the study area and other similar blighter neighbourhoods.
\end{abstract}

Index Terms-Housing problem, Neighbourhood, Nigeria, Private residential property, Property development.

\section{INTRODUCTION}

Housing has been a concern of individual, families, group and government since the down of urban civilisation.This Problem has often been associated to land acquisition problem, low income of the individual, high cost of building materials, statutory regulation, non use of local building materials etc. It is usually a situation of either the government has failed in meeting up with its obligations or that the individuals had remained for some times incapacitated to be able to break through various bureaucracies in land acquisition procedure. One of the greatest problems in the world today is that of provision of shelter. Shelter must not be only adequate for the population but also habitable. This problem is more pronounced in the urban areas where population pressure is on the increase. The problem of

Manuscriptt received July 15, 2011; revised July 31, 2011.

Authors are with Department of Construction and Real Estate Management, Faculty of Technology Management, Business and Entrepreneurship, Universiti Tuz Hussein Onn Malaysia, 86400, Parit Raja, Batu Pahat, Darul Ta'zim, Johor, Malaysia(e-mail: aaaliyu1978@yahoo.com rozilah@uthm.edu.my;martin@uthm.edu.my) looking for shelter leads to invasion of land for the purpose of building In Nigeria, the urban housing situation continues to deteriorate in the absence of an adequate arrangements to ensure that housing facilities expanded in line with the rapidly population growth. Despite the past efforts of the nation's housing problem, it was evident that the combined effort of the public and private sectors over the past successive government plans had continued to fall far short of housing need. Past governments had tended to leave this important sector almost entirely to private effort, concentrating itself on the provision of limited number of residential quarters for its deserving officers. Bowyer, (2008) noted that the major symptoms of urban housing problems include:-

- An absolute shortage of housing units.

- The emergence and proliferation of slums and squatter settlement especially in large cities.

- Rising house rents; and

- A growing inability of citizens to buy or build their own houses.

Individual effort to build or own a residence becomes quits difficult by the majority of the people subject to number of constraints. As a matter of fact the quality of life in any given environment is greatly influenced by the nature and standard of built up structures particularly residential properties (6). A cursory look at past housing policies and programmes in Nigeria reveals that effective solutions to housing problems in general and low income housing in particular are yet to be found. The housing situation has deteriorated continuously due to rapid natural population growth, increasing rural-urban migration etc. It is now generally agreed that most Nigerian states are facing a housing "crisis" of major proportion and a bounteous number of statistics and studies are available supporting this view

It is evident in Nigeria that in most cases objectives designed for a particular project are hardly ever realised. This is especially so when a critical look is made of the various government housing policies. For instance, Egunjobi, (2007) assessed the effectiveness of public low income housing programme in metropolitan Kano, which showed that the overall contribution of the programme in terms of increasing the supply of new housing required in metropolitan Kano was $50 \%$ of the planned target of 77,852 housing units for the period between 1975 and 1980. In addition, the low income group for whom the programme was meant did not constitute a substantial proportion of the eventual beneficiaries. . It is in the light of the above that this study seeks to investigate the nature and extent of the problems encountered by private developers when building residential accommodations in Makama Jahun neighbourhood of Bauchi Metropolis. The objectives of the study include: 
i) To determine the nature of land acquisition by the respondents in the study area.

ii) To make a market survey of the building materials used for housing construction in the study area (i.e. their cost and their availability and those use for housing construction in the study area).

iii) To ascertain the source of finance available to property developers in the study area.

iv) To proffer solutions to the identified problems in the study area

\section{THEORETICAL FRAMEWORK}

Housing has been a concern of individual, families, group and government since the down of urban civilisation \{Gilbert, (2007)\}.This Problem has often been associated to land acquisition problem. It is usually a situation of either the government has failed in meeting up with its obligations or that the individuals had remained for some times incapacitated to be able to break through various bureaucracies in land acquisition procedure.

Similar observations by both Abraham, (2006), Adebayo and Rowling (2007), Agbola \& Alabi, (2007) confirmed that housing situation, especially in urban centres has deteriorated continually due to rapid natural population growth and increasing rural urban migration among others. This undoubtedly supposed to serve as warning waves to government to evolve a workable policy concerning urban residential land use, and if this is meaningfully carried out, urban residential land use will at least, be free from the catalogue of land administration problems.

Abdul, (2008),Adeniyi,(2007),Bourne,(2007)\& Chatterjee, (2008)\} acknowledged too that housing problem manifest itself in many ways which include: conspicuous and residual house rent situation, an absolute scarcity of housing, the evolvement and proliferation of slums and squatter settlements, especially in large cities, lack of finance on the part of the citizen to construct their own house. The summary of Adamu's assertion is that housing problem, especially in our metropolis is virtually a function of the irregularities of urban land administration. This ugly situation according to him had unavoidably matured to a poor tenancy situation. The average urban dweller seems to be exhausted of all the possible options.

Egunjobi, (2007) noted that the majority of low income earners find it difficult to secure the loan or other form of assistance for building their own houses. Undoubtedly, the issue of building standard is one of the central problem in providing shelter for large majority of low income earners. On his critical observation of the general urban housing problem, Liman (1989) condemns that a policy that cannot guarantee every access to residential land by the poor, but rather encourages speculation and turn back to question the validity of individual tenure certainly erodes the basis of its acceptability. This is undoubtedly a chaining situation as far as urban land acquisition is concern. The attendant problem here is that land; though seem to be abundant but it is shared among the affordable individuals.

Bowyer, (2008), Dwyer, (2005) \&Gilbert, (2007) reasoned that the slow development of residential plots in our urban and emerging urban centres can also be attributed to non imposition of taxes on vacant land as done elsewhere. Such imposition of taxes discourages land hoarding as well as the fraudulent practice of multiple sales of a single plot to many prospective buyers which is common in parts of Nigeria. Similarly lack of readily available investment opportunities in the developing countries has made it safe for individual to invest on land, due to its unique qualities relatively to other resources.

Clois and Joan (2009) concluded that there is no doubting the fact that many developing countries blindly imitate foreign laws which were either imported from abroad or inherited as part of the colonial legacy. The developing countries should understand that these laws which were introduced by the colonist were meant to maintain their home countries status in the new era of territories they find themselves.

\section{Methodology}

Data were collected by interviews, self-administered surveys through questionnaire and direct observation. A total of 237 questionnaires were administered to the respondents. 200 valid responses were used to analyse the information pertaining to problems encountered by residential property developers when embarking on housing development. Data on building material and socio-economic characteristics of the respondents were obtained through interview. Data obtained from eighteen layouts (clusters) were used to test the association between income, occupation, education and extent of plot development in the study area

A field survey was conducted around the study area. The objective of the field survey is to reveal the extent of the area of operation and the likely difficulties to be encountered in carrying out the exercise. It enables easy interaction directly with the respondents in the area. It also helps to assess the level or extent to which the property developers abide by the planning and statutory regulations. The survey also gives an insight into the types of building materials used in housing construction. It helps to ascertain whether the acquire land formally or informally.

\begin{tabular}{|c|c|c|c|}
\hline S/NO & $\begin{array}{l}\text { Layout } \\
\text { (Cluster) } \\
\text { Number } \\
\end{array}$ & $\begin{array}{l}\text { Total number of plots } \\
\text { (partially and } \\
\text { undeveloped plots) }\end{array}$ & $\begin{array}{l}\text { Samples } \\
\text { Drawn }\end{array}$ \\
\hline 1 & $\mathrm{~S}: 1$ & 101 & 10 \\
\hline 2 & $\mathrm{~S}: 2$ & 73 & 7 \\
\hline 3 & S:3 & 74 & 7 \\
\hline 4 & $\mathrm{~S}: 4$ & 92 & 9 \\
\hline 5 & S:5 & 130 & 13 \\
\hline 6 & S:6 & 103 & 10 \\
\hline 7 & S:7 & 262 & 26 \\
\hline 8 & $\mathrm{~S}: 8$ & 13 & 1 \\
\hline 9 & S:9 & 81 & 8 \\
\hline 10 & $\mathrm{~S}: 10$ & 50 & 5 \\
\hline 11 & S:11 & 180 & 18 \\
\hline 12 & $\mathrm{~S}: 12$ & 117 & 11 \\
\hline 13 & $\mathrm{~S}: 13$ & 108 & 10 \\
\hline 14 & S:14 & 143 & 14 \\
\hline 15 & $\mathrm{~S}: 15$ & 210 & 21 \\
\hline 16 & S:16 & 137 & 13 \\
\hline 17 & $\mathrm{~S}: 17$ & 25 & 3 \\
\hline 18 & $\mathrm{~S}: 18$ & 140 & 14 \\
\hline \multicolumn{2}{|l|}{ Total } & 2039 & 200 \\
\hline
\end{tabular}


The stratified random sampling technique was employed in order to generate the data for the research. The entire layout (Makama Jahun area) was stratified into eighteen clusters. Each cluster represents a stratum that can be studied independently from others. Having stratified the layout, $10 \%$ of the plots i.e partially developed and undeveloped plots from each cluster were selected randomly using the table of random digits. (See table 1 below). Simple percentage distribution tables, chi-square analysis and narrations were used to analyse the data for the research. In other words, complete theoretical analysis was adopted for some data that are not numerical in nature. Data were further analysed through discussions. In essence theoretical, statistical and illustrative methods will be employed in data analysis because of their relevance to the data generated from the research.

\section{RESEARCH FINDINGS}

From table 2 below, it is evident that in the study area, the official plot allotters could not finally document their land acquisition formalities until after about one year (37\%). This period is indeed frustrating to so many people wishing to acquire land for residential purposes. The duration that is considered by many respondents as reasonable is the period between one to three months and as it can be seen from the table, this is represented by a small percentage (14\%). Greater respondents in the study area were not able to register their land between three to six months and six months to one year of application. Other findings revealed that those plot owners that were able to register their titles between 1-3 months had either used the influence of their position or wealth.

TABLE II: TIME TAKEN TO ACQUIRE REGISTERED PLOTS BY THE RESPONDENTS

\begin{tabular}{|l|l|l|}
\hline Time Taken & $\begin{array}{l}\text { Number of } \\
\text { Respondents }\end{array}$ & \% Frequency \\
\hline 1-3 Months & 14 & 7 \\
\hline 3-6 Months & 48 & 24 \\
\hline 6-12 Months & 64 & 32 \\
\hline After one year & 74 & 37 \\
\hline Total & 200 & 100 \\
\hline
\end{tabular}

TABLE III: DIFFICULTIES EXPERIENCED BY RESPONDENTS IN THE STUDY

\begin{tabular}{|l|l|l|}
\hline Difficulties & $\begin{array}{l}\text { Number of } \\
\text { Respondents }\end{array}$ & \% Frequency \\
\hline Deposit fee & 19 & 9.5 \\
\hline Processing fee & 11 & 5.5 \\
\hline $\begin{array}{l}\text { Reproduction of building } \\
\text { plan }\end{array}$ & 53 & 26.5 \\
\hline Reproduction of deeds & 7 & 3.5 \\
\hline Conversion process & 29 & 14.5 \\
\hline Staff attitude & 17 & 8.5 \\
\hline All of the above & 64 & 32 \\
\hline Total & 200 & 100 \\
\hline
\end{tabular}

Table 3 below shows that in Makama Jahun area, the entire respondents experienced problem at all levels; the greatest problem experienced by these respondents was production of building plans. Though, they had already acquired the land, they maintained that it was one of the stages that delayed the regulation of their plot. $5.5 \%$ of the respondents in the study area experienced the difficulty of processing fee; this is the fee that plot allotees have to settle in survey, town planning and land division before registering their titles. $8.5 \%$ however, suffered the problem that emanate from staff attitude. This is the attitude of staff in the three units of lands, survey and town planning.

This staff attitude manifest itself in the way and manners staffs deliberately delay acquisition of land in order to frustrate the efforts of applicants. This was discovered to be reasons why many respondents could not carry their land acquisition process to an end; in the contrary they often stopped at the level of issuing a grant right. In the same vein, $14.5 \%$ encountered difficulties of conversion process; this is the process of regularising lands that had earlier on, been given or acquired through the procedure of either ward head or local governments. $3.5 \%$ of the respondents in the study area faced problem of deed registration in land department. The nature of the building plan problem is in the number applicants are required to include in their application files. A minimum of eight building plans, according to many respondents are too much for residential purposes and consequently delay land acquisition process, more so that they are often rejected on the ground of non-conformity with the planning regulations.

Table 4 reveals that the most used procedure is through informal acquisition in the study area. This is followed by those who acquired their land through sale; that is, people acquired their land through purchase from hoarders. The least used procedure in land acquisition is that of gift. The procedure of sublease is fairly used too.

TABLE IV: ANALYSIS OF VARIOUS PROCEDURES FOR LAND ACQUISITION

\begin{tabular}{|l|l|l|l|}
\hline S/N & $\begin{array}{l}\text { Various Procedures of } \\
\text { Land Acquisition }\end{array}$ & $\begin{array}{l}\text { Number of } \\
\text { Respondent } \\
\text { s }\end{array}$ & $\begin{array}{l}\text { \% } \\
\text { Frequen } \\
\text { cy }\end{array}$ \\
\hline 1 & $\begin{array}{l}\text { Through informal } \\
\text { acquisition }\end{array}$ & 31.5 \\
\hline 2 & Through local government & 19 & 9.5 \\
\hline 3 & Through sale & 51 & 25.5 \\
\hline 4 & Through wardhead & 21 & 10.5 \\
\hline 5 & Through gift & 7 & 3.5 \\
\hline 6 & Through inheritance & 13 & 6.5 \\
\hline 7 & Through lease & 8 & 4 \\
\hline 8 & Through sublease & 12 & 6 \\
\hline 9 & Through pledge & 6 & 3 \\
\hline & Total & 200 & 100 \\
\hline
\end{tabular}

Now that the procedure of informal acquisition is seen to be dominant among all the rest method, the degree to which this method is properly observed becomes problematic because of the high prices charged by the land speculators. Most of the respondents who acquired their land through sublease indicated that the official consent process has not been formalised. This is a negation of the section 21 and 22 of the 1978 land use decree.

From Table 5 above, almost half of the respondents assessed the general land acquisition process to be very difficult $(92 \%)$. This is followed by those respondents who assessed the process as difficult $(82 \%)$. Putting these together, there are many respondents in the study area whose experience in land acquisition is not favourable. On the whole, therefore, majority of respondents in the study area had assessed land acquisition process to be either difficult or very 
difficult. This is a great obstacle to residential property development in the study area.

TABLE V: ASSESSMENT OF RESIDENTIAL LAND ACQUISITION PROCESS BY THE PROPERTY DEVELOPERS

\begin{tabular}{|l|l|l|}
\hline $\begin{array}{l}\text { Assessment } \\
\text { Formula }\end{array}$ & $\begin{array}{l}\text { Number of } \\
\text { Respondents }\end{array}$ & \% Frequency \\
\hline Very simple & 2 & 1 \\
\hline Simple & 3 & 1.5 \\
\hline Fair & 21 & 10.5 \\
\hline Difficult & 82 & 41 \\
\hline $\begin{array}{l}\text { Very } \\
\text { difficult }\end{array}$ & 92 & 46 \\
\hline Total & 200 & 100 \\
\hline
\end{tabular}

An examination of table 6 reveals that a larger proportion of respondents indicated bank loan as the source of finance for the development of their houses. For example, 73.5\% of the sample respondents indicated Bank loan as their main source of fund, while those who indicated personal saving account for only $17.5 \%$ of the total respondents. Those respondents who indicated Bank loan as their main source of fund have since realised that their expected source can no longer be applicable. This is because of the collateral security needed by the Bank before issuing the loan which most of the respondents do not have.

TABLE VI: SOURCE OF FINANCING DEVELOPMENT BY THE RESPONDENTS

\begin{tabular}{|l|l|l|}
\hline Source of Fund & Number of Respondents & \% Frequency \\
\hline Personal Saving & 35 & 17.5 \\
\hline Bank Loan & 147 & 73.5 \\
\hline Saving/ Bank Loan & 11 & 5.5 \\
\hline Housing Loan & 7 & 3.5 \\
\hline Total & 200 & 100 \\
\hline
\end{tabular}

While those indicated personal saving as their source of fund to develop their houses, complained that now their daily and monthly income cannot even meet their demands let alone save some for building a house. As a result of loosing the expected source of fund for building their houses and other pressures of life pushed some of the respondents to enter into the land market and sell out their plots. This undoubtedly encouraged land speculation and the slow development of the residential plots in the study area.

Table 7 indicates that of such respondents who preferred using their personal income, 19.5 Percent had to save between 3-8 years; whereas 62.5 percent saved for more that 8 years. Information from interview conducted revealed that their general annual incomes range between $\$ 60,000-\$ 170$, 000 .

TABLE VII: TIME TAKING FOR THE RESPONDENT TO SAVE MONEY

\begin{tabular}{|l|c|c|}
\hline Time & Number of Respondents & \% Frequency \\
\hline Less than one year & 13 & 6.5 \\
\hline 1-2 years & 23 & 11.5 \\
\hline 3-8 years & 39 & 19.5 \\
\hline More than 8 years & 125 & 62.5 \\
\hline Total & 200 & 100 \\
\hline
\end{tabular}

One of the basic conditions for grant of statutory certificate of occupancy is that the lease- hold grantee must effect development within two years. After this period the certificate of occupancy could be revoked any moment. If therefore it takes so long for people within N60,000-N 170,000 annual income range to save (that is longer than the period stipulated for development) then the issue of using personal income only to carry out land development becomes a problem. Other sources of finance available to property developers in the study area include:

(a) Personal Borrowing: - For private and individual development, loan finance is usually sourced from friends and relations to supplement the developer's own capital. However, the amount of money raised from this source by the property developers is usually small which makes it not suitable for residential property development. Borrowed funds may also be sourced from local money lenders. This is usually arranged through written agreement but the interest rate is very high since it is not regulated.

(b) Cooperative Credit and Thrift Societies, this is called "Adashe" in the study area the societies grant loans to members from fund raised through minimum monthly mandatory savings in the shares and saving account. Members obtain loans from the society by taking turns and collecting periodic contributions, which are given to members in a predetermined order. However, this was found to be inadequate because of the huge capital outlay required for housing development by the property developers in the study area.

(c) Trade Credit: - This is an arrangement made between the property developers and the building material merchant. Building materials are often sold to private property developers on credit in which the developers pay for the materials at future date. The merchants usually sell at higher prices than the current market price to cater for risk of possible increase in price on a future date. This source of financing residential property development was also found to be insignificant because most of the respondents interviewed indicated that they were unable to repay back the money. This eventually caused serious problem and in some cases the court intervene in order to settle the dispute.

Other sources of finance which encompasses short term loans, medium term loans and long term loans credit facilities that are public in nature have little or no impact to most private property developers in the study area.

TABLE VIII: RELATIONSHIP BETWEEN OCCUPATION AND EXTENT OF PLOT DEVELOPMENT

\begin{tabular}{|c|c|c|c|c|}
\hline \multicolumn{5}{|c|}{ DEVELOPMENT } \\
\hline \multirow{2}{*}{ Occupation } & \multirow{2}{*}{$\begin{array}{l}\text { Sample } \\
\text { size }(\mathbf{N})\end{array}$} & \multicolumn{3}{|c|}{ Extent of Plot Development } \\
\hline & & $\begin{array}{c}\text { Partially } \\
\text { developed }\end{array}$ & $\begin{array}{c}\text { Undevelope } \\
\text { d }\end{array}$ & $\begin{array}{c}\text { Tota } \\
1\end{array}$ \\
\hline Civil service & 95 & 60 & 35 & 95 \\
\hline $\begin{array}{l}\text { Business/Tra } \\
\text { ding }\end{array}$ & 74 & 45 & 29 & 74 \\
\hline $\begin{array}{l}\text { Private } \\
\text { service }\end{array}$ & 21 & 14 & 7 & 21 \\
\hline Farming & 10 & 4 & 6 & 10 \\
\hline Total & 200 & 123 & 77 & 200 \\
\hline
\end{tabular}

Table 8 generally illustrates that higher rate of partially developed and totally undeveloped plots are owned by the civil servants, business men/traders and private service while farmers account for the lower proportion of the partially and undeveloped plots. When the above frequency distribution on table 12 was subjected to $\mathrm{x}^{2}$ analysis, it was found that a $\mathrm{x}^{2}$ value of 2.314 at 3 degrees of freedom (df) was significant at the 0.01 level. The table value at 3 degrees of freedom (df) is 0.115 at 0.01 level of significance. Hence 
TABLE IX: RELATIONSHIP BETWEEN INCOME AND EXTENT OF PLOT DEVELOPMENT

\begin{tabular}{|c|c|c|c|c|}
\hline \multirow{2}{*}{ Income } & \multirow{2}{*}{$\begin{array}{c}\text { Sample } \\
\text { size (N) }\end{array}$} & \multicolumn{3}{|c|}{ Extent of Plot Development } \\
\cline { 3 - 5 } & $\begin{array}{c}\text { Partially } \\
\text { developed }\end{array}$ & Undeveloped & Total \\
\hline $\begin{array}{c}\text { Below N } \\
60,000\end{array}$ & 15 & 9 & 6 & 15 \\
\hline $70,000-95,000$ & 35 & 24 & 11 & 35 \\
\hline $\begin{array}{c}96,000-140,00 \\
0\end{array}$ & 38 & 27 & 11 & 38 \\
\hline $\begin{array}{c}141,000-250,0 \\
00\end{array}$ & 34 & 24 & 10 & 34 \\
\hline $\begin{array}{c}251,000-300,0 \\
00\end{array}$ & 40 & 30 & 10 & 40 \\
\hline Over 300,000 & 38 & 25 & 13 & 38 \\
\hline Total & 200 & 139 & 61 & 200 \\
\hline
\end{tabular}

A chi-square (x2) analysis confirms the view that income of plot holder determines his extent of plot development as the $\mathrm{x} 2$ value of 1.533 at 5 degrees of freedom was significant at the 0.01 levels. The table value at 5 degrees of freedom is 0.554 at 0.01 level of significance. Therefore, we rejected the null hypothesis which stated there was no association between extent of plot development and income status of the respondent (Table 9)

\section{CONCLUSION}

This paper has attempted a description and explanation of the problems of private residential property development in Makama Jahun neighbourhood of Bauchi metropolis. Through the study carried out, it was realised that among the most important or prevailing problems affecting private residential property development in the study area include:Problem of land acquisition, housing finance, building materials, statutory regulation among others.

Land virtually remains a factor negatively affecting housing development in the study area due to incessant failure of developers to get title to land. The long period of awaiting Right of Occupancy ( $\mathrm{R}$ of $\mathrm{O}$ ) and Certificate of Occupancy $(\mathrm{C}$ of $\mathrm{O})$ is an outstanding obstacle to residential property development in the study area.The payment of numerous fees by developers at various stages of preparation of the legal document discourages developers to continue with the struggle for land acquisition. Eventually, some of the respondents resort to informal way of land acquisition which is financially cumbersome.

The activities of hoarders also discourage land development in the study area. The landowners that are not capable of developing them are not willing to sell their lands to the potential developers because they want to sell it at an exorbitant price. . The remaining available land for sale attracts high price. This excessive rate shorts up development costs. High cost of building materials has been identified as one of the major problems militating against adequate residential property development in the study area. Generally, the problems have included that of scarcity and high cost of imported building materials or those with foreign components.

In the study area, most developers do travel out to buy building materials in bulk to enable them realise some discounts as there is no building materials industry in Bauchi apart from asbestos roofing sheet industry. As earlier mentioned, this is due to the inflationary pressure in the economy which contributed excessively to the present rise in the cost of building materials, most especially when the building materials are imported.

Unless these problems are taken as challenges or are addressed promptly in the study area, the problem of residential property development in Makama area is likely to remain for sometime. Indeed, without the total commitment and involvement of both private and public sector, there will be no long lasting solution to the identified problems. Thus, while trying to provide a long lasting solution to the problems in the study area, it is advised and hope that those involved in the provision of residential accommodation would look at it as a challenge as well as race that is fast moving ahead of time in the study area. For the purpose of overcoming the problems of private residential property development in Makama Jahun area, the following recommendations and suggestions are made:-

(1) There is a need to reduce the level of bureaucracy associated with land acquisition and thereby quicken acquisition process in the study area. It is necessary to reduce the chain of schedule in formal land acquisition. This will go a long way to facilitate efficient residential property development in the study area. This may not however be possible until when land officers are exposed to broad training on simple map interpretations in cadastral surveying. This can enable them to confirm space under application, instead of forwarding that to survey department. Survey department can however continue with its traditional function of charting the layout and monitoring of such charts too.

(2). For effective and efficient land acquisition to be put in place in the study area, there is the need to revisit the issue of land fees charged currently and the basis of determination, especially in respect of residential need. The fixing of land fees by the state chief executive should rather be handled by a special committee that should be made up of professionals in land- related disciplines. This is necessary because most of the state chief executives who are mandated by the land use decree to fix land charges are not all professionals and therefore lack the professional skill with which to assess land values.

(3). the use of local building materials should be encouraged by the government. The property developers should on their own use such building materials in the construction of their houses to demonstrate to the society that they are functional and durable. Also the government should grant subsidy to the industries manufacturing such local building materials until the society develops enough taste for such product to stimulate substantial demand.

(4). Emphasis should be on functional design with economy of material uppermost by the property developers in the study area. Design type obviously has a direct effect on development cost, the realities of our time does not give any room for flamboyancy in design if we actually appreciate the meaning of residential property.

(5) Enforcing penalty for none development of allocated plots:- This measures will be taken in order to reduce the problem of land speculation which is one of the important factors explaining the delay in the development of residential 
plots in the study area. Government should enforce a strict compliance with the conditions stated in the allocation paper. Where allottee fails to effect development on his plot after five years, the title to such land should be revoked. This measure becomes necessary because the two years development, period is too short considering the present economic condition of the country, and the rate at which the plots are left undeveloped in different residential layouts within the metropolis.

(6). Delay in disposing urban land: - The Government should avoid unnecessary delay in disposing urban residential land to genuine developers. In order to implement this effectively, right measures have to be taken in allocating the residential plots to most deserving applicants not to those who use the avenue as opportunity for making fortune. In addition to this, government and other financial institutions, should introduce and give out soft loan to developers, to facilitate plot development, particularly, the low income these groups. To implement this successfully loan should be inform of some building materials, such as cements roofing sheet etc.

\section{ACKNOWLEDGMENT}

The author wants to humbly and sincerely appreciate the assistance and kind gesture of his main and co-supervisor Dr. Rozilah Kasim and Dr. David Martin respectively for their untiring constructive criticism, suggestions, observations and guidance. Special thanks also go to my research colleagues, department heads, and University Tun Hussein Onn Malaysia who sponsored this research. I say a big thanks to all of you

\section{APPECDIX}

\section{TRENDS IN THE AVERAGE PRICE OF BUILDING MATERIAL S IN} BAUCHI METROPOLIS BETWEEN 2009- 2010

The table below shows that the cost of building materials has maintained an upward trend over the years even though there are price fluctuations depending on the economic situation, market forces, material availability and period of construction (i.e. whether on or off construction seasons). All the materials surveyed experienced increased in their prices. For instance, the price of cement increases by $23.5 \%$ between 2008 and 2009, while roofing zinc increased by $30 \%$ in the same period. The same trend goes for gravel, asbestos ceiling board, steel door and wall tiles whose prices increased by $25 \%, 33.3 \%, 16.7 \%$, and $8.3 \%$ respectively in the period under review.

\begin{tabular}{|c|c|c|c|c|}
\hline \multirow[t]{2}{*}{ Type of materials } & \multicolumn{2}{|c|}{$\begin{array}{l}\text { Average prices } \\
\text { per item (in } \\
\text { Naira) over the } \\
\text { years }\end{array}$} & \multirow[t]{2}{*}{$\begin{array}{l}\text { Absolute } \\
\text { Increase }\end{array}$} & \multirow[t]{2}{*}{$\begin{array}{l}\% \\
\text { Incre } \\
\text { ase }\end{array}$} \\
\hline & 2008 & 2009 & & \\
\hline Cement & 1,700 & 2,100 & 400 & 23.5 \\
\hline Load of Gravel & 1,200 & 1,500 & 300 & 25 \\
\hline Load of shaft sand & 700 & 900 & 200 & 28.6 \\
\hline Load of plaster sand & 800 & 1,100 & 300 & 37.5 \\
\hline $2 \times 2 \times 12$ plank & 150 & 200 & 50 & 33.3 \\
\hline $2 \times 3 \times 12$ plank & 250 & 350 & 100 & 40 \\
\hline $2 \times 4 \times 12$ plank & 350 & 500 & 150 & 42.9 \\
\hline $1 \times 12 \times 12$ plank & 950 & 1,200 & 250 & 26.3 \\
\hline
\end{tabular}

\begin{tabular}{|l|l|l|l|l|}
\hline $3 / 4$ plywood & 1,800 & 2,200 & 400 & 22.2 \\
\hline 1 bundle of roofing zinc & 10,000 & 13,000 & 3,000 & 30 \\
\hline Asbestos roofing sheet & 15,000 & 17,000 & 2,000 & 13.3 \\
\hline Asbestos ceiling board & 900 & 1,200 & 300 & 33.3 \\
\hline Particle ceiling board & 900 & 1,100 & 200 & 22.2 \\
\hline Steel door (single) & 12,000 & 14,000 & 2,000 & 16.7 \\
\hline Flush door & 3,000 & 4,000 & 1,000 & 33.3 \\
\hline $10 \mathrm{~mm}$ iron bar & 2,500 & 3,500 & 1,000 & 40 \\
\hline $12 \mathrm{~mm}$ iron bar & 2,500 & 4,000 & 1,500 & 60 \\
\hline $14 \mathrm{~mm}$ iron bar & 3,000 & 4,500 & 1,500 & 50 \\
\hline $\begin{array}{l}\text { A bag of 4 inch china } \\
\text { nail }\end{array}$ & 6,000 & 7,000 & 1,000 & 16.7 \\
\hline $\begin{array}{l}\text { A bag of 3 inch china } \\
\text { nail }\end{array}$ & 6,500 & 7,500 & 1,000 & 15.4 \\
\hline $\begin{array}{l}\text { A pocket of 2 1/2 inch } \\
\text { zinc nail }\end{array}$ & 6,000 & 6,500 & 500 & 8.3 \\
\hline $3 / 4$ inch galvanised pipe & 1,700 & 2,000 & 300 & 17.6 \\
\hline 1/2 inch galvanised pipe & 1,500 & 1,700 & 200 & 13.3 \\
\hline 4 inch PVC pipe & 550 & 650 & 100 & 18.2 \\
\hline $\begin{array}{l}\text { Wash hand basin } \\
\text { (Nigeria) }\end{array}$ & 7,000 & 8,000 & 1,000 & 14.3 \\
\hline Shower basin & 4,000 & 4,500 & 500 & 12.5 \\
\hline $\begin{array}{l}\text { W/C and Flush } \\
\text { Accessories }\end{array}$ & 7,000 & 7,500 & 500 & 7.1 \\
\hline $\begin{array}{l}\text { Crate of Wall } \\
\text { Tiles (Abeokuta) }\end{array}$ & 600 & 650 & 50 & 8.3 \\
\hline $\begin{array}{l}\text { Emulsion paint (4 liters } \\
\text { of Bonalux) }\end{array}$ & 500 & 600 & 100 & 20 \\
\hline
\end{tabular}

\section{REFERENCES}

[1] Abdul, A.A. (2008). Time Lag in the Development of Urban Residential Plots in Kano Metropolis. An Unpublished M.Sc. Thesis, Geography Department, Bayero University Kano.

[2] Abiodun. J. (2008). Housing Problems in Nigerian Cities. National Institute of Social and Economic Research (NISER). Intec Printers, Ibadan.

[3] Abraham, C. (2006). Man's Struggle for Shelter in an Urbanising World. Massachusetts Institute of Technology Press, U.S.A.

[4] Adamu, E.O. (2007). The Private Development of Residential Land Subject to Statutory Title in Makurdi, Benue State, Nigeria. Unpublished M. Sc Thesis. Bayero University, Kano.

[5] Adebayo, A. and Rowling, L. (2007). Management Problems of Rapid Urbanisation in Nigeria. University of Ife Press, Ile -Ife, Nigeria.

[6] Ademola, T.S. (2006). Nigeria's Housing Policies and Programmes: A Preliminary Assessments. Butgers University, U.S.A.

[7] Adeniyi, E.O. (2008) Challenges of Provision of Housing in Nigeria's Urban Centres. Third International Conference on Housing. Years of Housing Development in Africa: Paper 1CH/12 Kaduna.

[8] Adeniyi, E.O. (2007). Housing and the Construction Industry in Nigeria, Nigerian Institute of Social and Economic Research (NISER) Intec Printers, Ibadan

[9] Agbola, T. Alabi, O. (2007). Major Problems of Housing in Nigeria .A Paper presented at the Workshop on Housing Organised by Bobabin Nig. Ltd, Held at Grennspring Hotel, Ibadan.

[10] Agbola, T. (2009). Projection of Urban Housing Needs NISER, Ibadan.

[11] Bourne, L.S. (2007) A Geography of Housing. Edward Arnold, London

[12] Bowyer, J. (2008) Building Technology. The Butterwort Group, United Kingdom

[13] Chatterjee, E. (2008) Urbanisation Trends and Problems of Urban Housing in Nigeria. Ibadan University Press, Ibadan.

[14] Clois, E.K. and Joan, C.K. (2009) Residential Housing. The Goodheart Willcox Company, Inc. South Holland Illinois.

[15] Dwyer, D.J. (2005) People and Housing in Third World Cities. Longman Group Limited, London.

[16] Egunjobi, L. (2007) Housing Affordability and the Nigerian Poor. A Paper Presented at the Staff/Postgraduate Students Seminar 1997/1998 Session, Geography Department, University of Ibadan, Ibadan.

[17] Gilbert, A. (2007) the Housing of the Poor. In Gilbert A. and Gugler J. (ed) Cities, Poverty and Development: Urbanisation in the Third World. Oxford University Press. Minna 